University of Nebraska - Lincoln

DigitalCommons@University of Nebraska - Lincoln

\title{
One-year changes in glucose and heart disease risk factors among participants in the WISEWOMAN programme
}

\author{
JC Will \\ Centers for Disease Control and Prevention, jwill@cdc.gov \\ O Khavjou \\ Research Triangle Park, okhavjou@rti.org \\ EA Finkelstein \\ Research Triangle Park, finkelse@rti.org \\ RK Loo \\ Centers for Disease Control and Prevention \\ KY Gregory-Mercado \\ Centers for Disease Control and Prevention
}

Follow this and additional works at: https://digitalcommons.unl.edu/publichealthresources

Part of the Public Health Commons

Will, JC; Khavjou, O; Finkelstein, EA; Loo, RK; and Gregory-Mercado, KY, "One-year changes in glucose and heart disease risk factors among participants in the WISEWOMAN programme" (2007). Public Health Resources. 276.

https://digitalcommons.unl.edu/publichealthresources/276

This Article is brought to you for free and open access by the Public Health Resources at DigitalCommons@University of Nebraska - Lincoln. It has been accepted for inclusion in Public Health Resources by an authorized administrator of DigitalCommons@University of Nebraska - Lincoln. 


\title{
One-year changes in glucose and heart disease risk factors among participants in the WISEWOMAN programme
}

\author{
JC Will, ${ }^{\star}$ O Khavjou, EA Finkelstein, RK Loo, KY Gregory-Mercado
}

\section{Introduction}

Over time, the prevalence of prediabetes (fasting blood glucose 5.5-6.9 $\mathrm{mmol} / \mathrm{l}$ ) and diabetes has increased in the United States (US). ${ }^{1-3}$ People with diabetes have a higher risk of heart disease and stroke than people without diabetes, ${ }^{4}$ and those with prediabetes have a higher risk of these diseases than those without the precondition. ${ }^{4-7}$ Thus, intervention programmes are needed to prevent both pre-diabetes and diabetes and to control heart disease risk factors among people with these conditions.

The Well-Integrated Screening and Evaluation for Women Across the Nation (WISEWOMAN) ${ }^{8,9}$ project is a

\section{Authors \\ JC Will, ${ }^{1} \mathrm{PhD}, \mathrm{MPH}$ \\ O Khavjou, ${ }^{2}$ MA \\ EA Finkelstein, ${ }^{2} \mathrm{PhD}, \mathrm{MHA}$ \\ RK Loo, ${ }^{1} \mathrm{PhD}$ \\ KY Gregory-Mercado, ${ }^{1} \mathrm{PhD}, \mathrm{MPH}$ \\ ${ }^{1}$ Centers for Disease Control and \\ Prevention, Division for Heart Disease and \\ Stroke Prevention, Atlanta, GA \\ ${ }^{2}$ RTI International, Health, Social and \\ Economics Research, Research Triangle \\ Park, NC, USA \\ ${ }^{*}$ Correspondence to: \\ JC Will, PhD, Division for Heart Disease and Stroke Prevention, National Center for Chronic Disease Prevention and Health Promotion, Centers for Disease Control and Prevention, 4770 Buford Highway NE, MS K-77, Atlanta, GA 30341, USA e-mail: jwill@cdc.gov}

Received: 07 November 2006 Accepted in revised form: 12 February 2007

\begin{abstract}
Background: WISEWOMAN provides chronic disease risk factor screening, referrals and lifestyle interventions to low-income, uninsured women, to reduce their heart disease and stroke risk. Participants learn behaviour-changing skills tailored to low-income populations, such as collaborative goal setting, the need to take small steps and other empowerment techniques.

Aim: To quantify the baseline prevalence of pre-diabetes (fasting blood glucose 5.5-6.9 mmol/l) and diabetes among WISEWOMAN participants and assess oneyear changes in glucose levels and other diabetes risk factors.

Methods: We used 1998-2005 baseline and one-year follow-up data from WISEWOMAN participants. Using a multilevel regression model, we assessed one-year changes in glucose, blood pressure (BP), total cholesterol and 10-year risk of coronary heart disease (CHD) among participants with baseline pre-diabetes $(n=688)$ or diabetes $(n=338)$. Results: At baseline, $15 \%$ of participants had pre-diabetes and $10 \%$ had diabetes. Of those with diabetes, $26 \%$ were unaware of their condition before baseline screening During the one-year follow-up period, participants with pre-diabetes experienced statistically significant improvements in glucose (2.9\%) and cholesterol $(2.1 \%)$ levels and 10 -year $\mathrm{CHD}$ risk (4.3\%). Participants with newly diagnosed diabetes experienced statistically significant improvements in glucose (11.5\%), BP $(3.1 \%-3.5 \%)$ and cholesterol (6.4\%) levels. Participants with previously diagnosed diabetes experienced significant improvements in BP (1.9-3.4\%), cholesterol level (3.8\%), and 10-year CHD risk $(8.5 \%)$.

Conclusions: Implementing patient-centered, comprehensive and multilevel interventions and demonstrating their effectiveness will likely lead to the adoption of this approach on a much broader scale.
\end{abstract}

Eur Diabetes Nursing 2007; 4(2): 57-63.

\section{Key Words}

Diabetes, cardiovascular disease, prevention, women, medically uninsured, screening

US Centers for Disease Control and Prevention (CDC) funded, multicomponent intervention programme aimed at reducing heart disease and stroke risk in low-income, underinsured, and uninsured women aged 40-64 years. WISEWOMAN provides preventive services including blood pressure (BP), cholesterol, and glucose screening; lifestyle interventions to help women develop a healthier diet, increase physical activity, and quit smoking; referrals for medical treatment for participants with abnormal values; and one-year follow-up visits to provide feedback to participants and their providers about changes in participants' risk factor profiles. ${ }^{9}$ The goal of the programme is to improve participants' health by reducing risk, by offering heart disease and strokeprevention activities in conjunction with the National Breast and Cervical Cancer Early Detection Program (NBCCEDP).

Patient-centered lifestyle programmes are especially important for low-income women because they typically receive inconsistent care. For example, roughly one in five $(18 \%)$ working-age women in the US lacks health insurance, ${ }^{10}$ and ethnic 
minority women - even when insured - are less likely than white women to have a consistent relationship with a healthcare provider. ${ }^{11}$ Ensuring access to preventive health serv-ices requires expanding healthcare coverage, and fostering consistent and trusting relationships between providers and patients. ${ }^{12}$ Thus, preventive healthcare strategies that are sensitive to the economic and cultural context of women's lives are needed.

With funding from Congress in 1995, CDC invited state and territorial departments of health and tribal agencies to design creative strategies that would add cardiovascular disease (CVD) screening and lifestyle interventions to breast and cervical cancer screening programmes. Fifteen state and tribal health agencies now operate WISEWOMAN projects (Figure 1).

Using social cognitive theory and the socio-ecological model, WISEWOMAN interventions are tailored to each woman and are designed to improve participants' selfefficacy, self-monitoring, readiness to change, social support, collaborative goal-setting and ability to overcome barriers, by taking small achievable steps. Many projects also use motivational interviewing. 8,9

Baseline fasting glucose levels appear to be increasing in WISEWOMAN participants (Figure 2), especially in comparison with the levels in the general US population (National Health and Nutrition Examination Study, 1999-2004). ${ }^{13}$ Therefore, understanding whether participation in the WISEWOMAN programme improves health outcomes is important for planning diabetes prevention efforts. The goal of this paper is to quantify the baseline prevalence of pre-diabetes and diabetes in WISEWOMAN participants, and assess one-year changes in glucose levels and other heart disease and stroke risk factors.

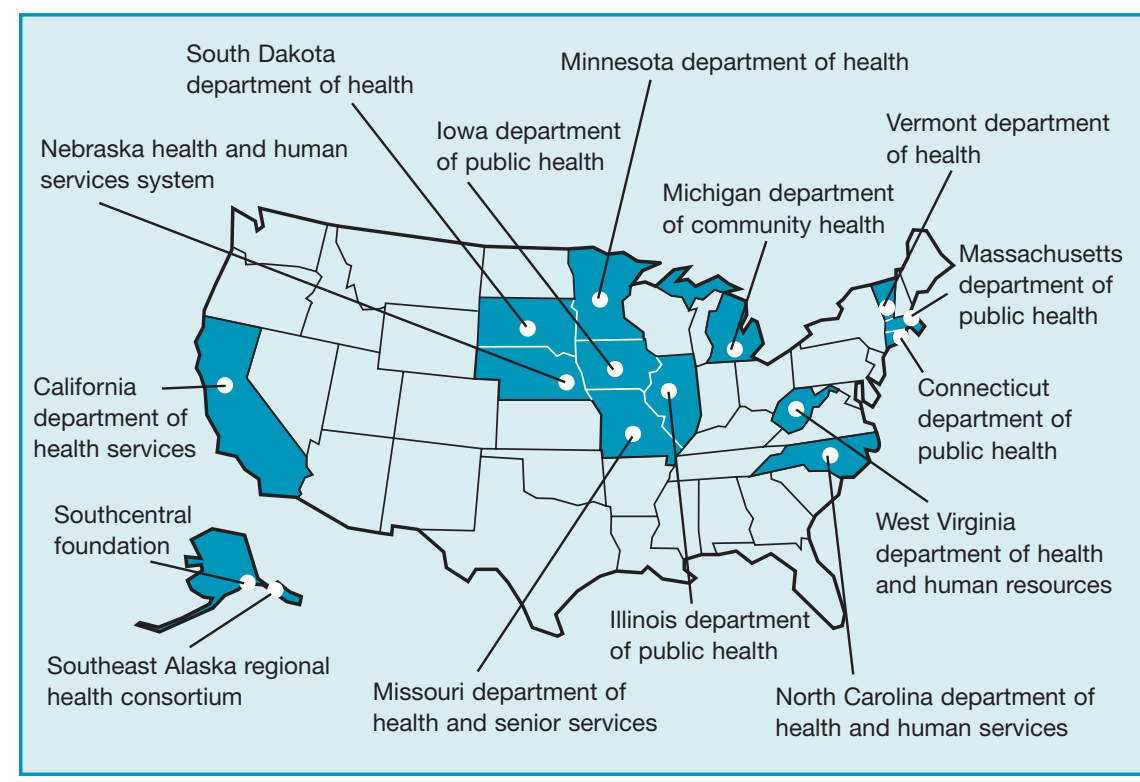

Figure 1. Location of WISEWOMAN projects funded in 2006

\section{Methods \\ WISEWOMAN projects}

We restricted our analysis to the 10 WISEWOMAN projects that offer diabetes and pre-diabetes screenings and, at the time of the analysis, had both baseline and one-year follow-up data on participants.

\section{Data Collection}

Programme participants were screened at baseline and again 1014 months later to assess changes in risk factors. For measurements of BP and cholesterol, WISEWOMAN projects follow guidelines from the Joint National Committee ${ }^{14}$ and the Adult Treatment Panel $^{15}$ for detection, evaluation and treatment of high BP and cholesterol levels, respectively. For example, all projects measured BP twice during each visit.

At baseline and one-year followup, all projects measured height, weight, systolic and diastolic BP, total and high-density lipoprotein (HDL) cholesterol levels, and blood glucose levels. Participants were also asked whether they had ever been diagnosed as having diabetes, high cholesterol, or hypertension and if so, whether they were taking medication to treat these conditions. Participants also indicated whether they smoked cigarettes. The programmes collected demographic data on age, race, Hispanic or Latino origin, and education. The WISEWOMAN data collection protocol has been approved by the RTI International institutional review board.

\section{Definitions}

Based on American Diabetes Association guidelines, participants were considered to have pre-diabetes if they had fasting blood glucose levels of 5.5-6.9 mmol/1. They were considered to have diabetes if they had fasting blood glucose levels of $\geq 7 \mathrm{mmol} / \mathrm{l}$ or a self-reported history of diabetes, or if they were taking medication for diabetes. ${ }^{5}$ Participants who were newly diagnosed with diabetes were those with abnormal glucose values at baseline (i.e. fasting blood glucose levels $\geq 7$ $\mathrm{mmol} / \mathrm{l}$ ) who reported that they had never been told by a healthcare professional that they had diabetes. Participants with previously diagnosed diabetes were defined as those who reported having been told by a healthcare professional that they had diabetes. ${ }^{4,5}$ 


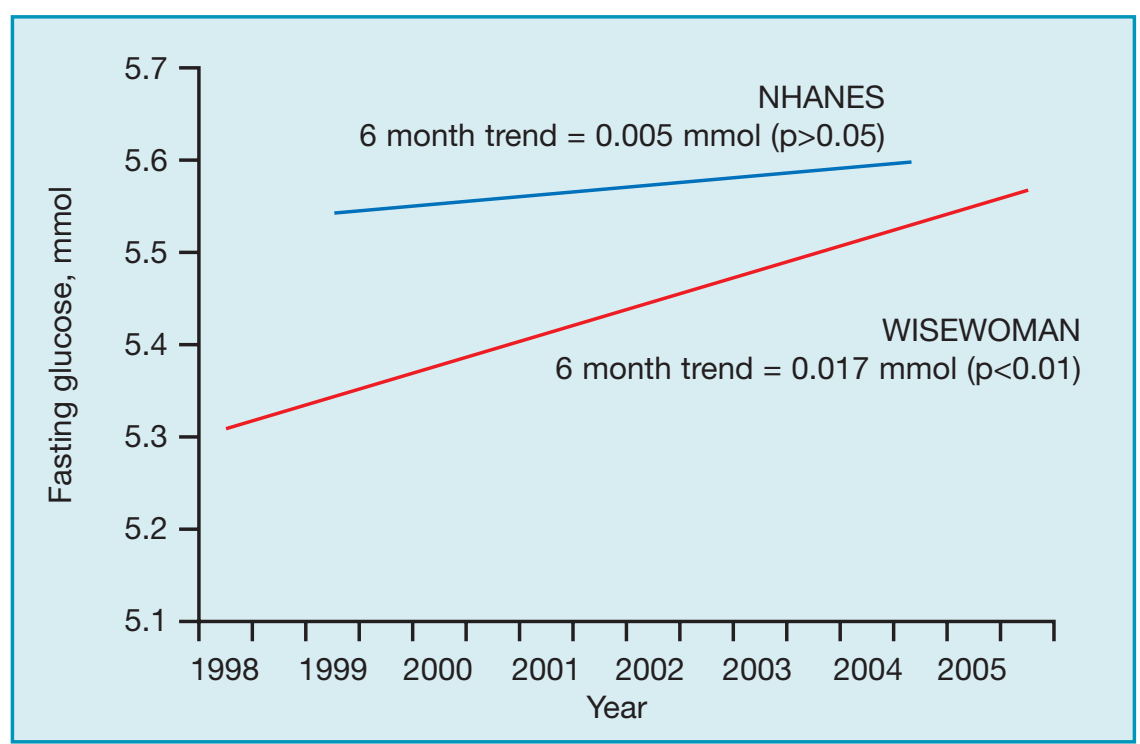

Figure 2. Mean fasting blood glucose values in the US (1999-2004) and in the WISEWOMAN programme (1998-2005)

\section{Measures}

We assessed baseline prevalence of pre-diabetes and diabetes and the percentage of newly diagnosed cases of diabetes among 29387 WISEWOMAN participants screened at baseline between January 1998 (North Carolina is the only project for which screening data are available from 1998. Other projects began screening from 2000 onwards) and June 2005. A total of $23 \%$ of programme participants screened at baseline were re-screened one year later. We assessed one-year changes in CHD risk factors (systolic and diastolic $\mathrm{BP}$, total cholesterol, fasting blood glucose, body mass index [BMI], smoking prevalence, and 10-year risk of CHD) in 688 WISEWOMAN participants with baseline pre-diabetes, 83 participants with newly diagnosed diabetes at baseline, and 260 participants with previously diagnosed diabetes.

We calculated the 10-year risk of developing CHD (including angina pectoris, recognised and unrecognised myocardial infarction, coronary insufficiency [unstable angina], and CHD death) with an algorithm developed by Anderson et $a l^{16}$ that uses age, systolic BP, total and HDL cholesterol, diabetes and smoking status as input risk factors. Our rationale for selecting this algorithm was based on our previous work demonstrating the Anderson algorithm to be the most appropriate calculator for tracking changes in CHD risk among WISEWOMAN participants. ${ }^{17}$ Age and diabetes status remained unchanged from baseline to follow-up when calculating changes in $\mathrm{CHD}$ risk. ${ }^{17}$

\section{Analysis}

We estimated one-year changes in risk factors using ordinary least squares regression analysis with the specified risk factor as the dependent variable and the indicator for baseline or follow-up visit as the independent variable. We ran separate regressions for women with baseline pre-diabetes, newly diagnosed diabetes, and previously diagnosed diabetes. To control for correlation among participants who were nested within local project sites, we ran a multilevel mixed model, with participant identification (ID) and state/tribal organisation ID as grouping variables using the xtmixed command in Stata. ${ }^{18,19}$ P-values $\leq 0.05$ were considered significant.

\section{Results}

Demographic characteristics of the WISEWOMAN participants are listed in Table 1. The percentages of women with pre-diabetes and diabetes, including the numbers of those newly diagnosed, are given in Figure 3. The demographic characteristics of the women differed by diabetes status (Table 1).

WISEWOMAN participants who returned for their one-year follow-up examination showed several statistically significant improvements in CVD risk factors (Table 2). Participants with pre-diabetes experienced statistically significant reductions in fasting blood glucose level (by $0.17 \mathrm{mmol} / 1$ or $2.9 \%, \mathrm{p}<0.01$ ), total cholesterol level (by $0.11 \mathrm{mmol} / 1$ or $2.1 \%, \mathrm{p}<0.01$ ), and 10-year CHD risk (by $4.3 \%, \mathrm{p}<0.05$ ). Participants with newly diagnosed diabetes experienced statistically significant reductions in fasting blood glucose level (by $0.96 \mathrm{mmol} / \mathrm{l}$ or $11.5 \%$, $\mathrm{p}<0.05$ ), systolic BP (by $4.2 \mathrm{mmHg}$ or $3.1 \%, \mathrm{p}<0.05$ ), diastolic BP (by $2.9 \mathrm{mmHg}$ or $3.5 \%, \mathrm{p}<0.05)$, and total cholesterol level (by $0.36 \mathrm{mmol} / 1$ or $6.4 \%, \mathrm{p}<0.01)$. Participants with previously diagnosed diabetes experienced statistically significant reductions in systolic BP (by $2.5 \mathrm{mmHg}$ or $1.9 \%, \mathrm{p}<0.05$ ), diastolic BP (by $2.7 \mathrm{mmHg}$ or $3.4 \%, \mathrm{p}<0.01)$, total cholesterol level (by $0.21 \mathrm{mmol} / 1$ or $3.8 \%, \mathrm{p}<0.01)$, smoking rates (by 3.8 percentage points or $23.8 \%, \mathrm{p}<0.01)$, and 10-year CHD risk (by 1.1 percentage points or $8.5 \%, \mathrm{p}<0.01)$

\section{Discussion}

Our results showed that WISEWOMAN participants were at high risk of diabetes-related complications at baseline and that their mean blood glucose values were increasing over time (Figure 2), emphasising the need for programmes like WISEWOMAN, which reduce fasting blood glucose values and control 


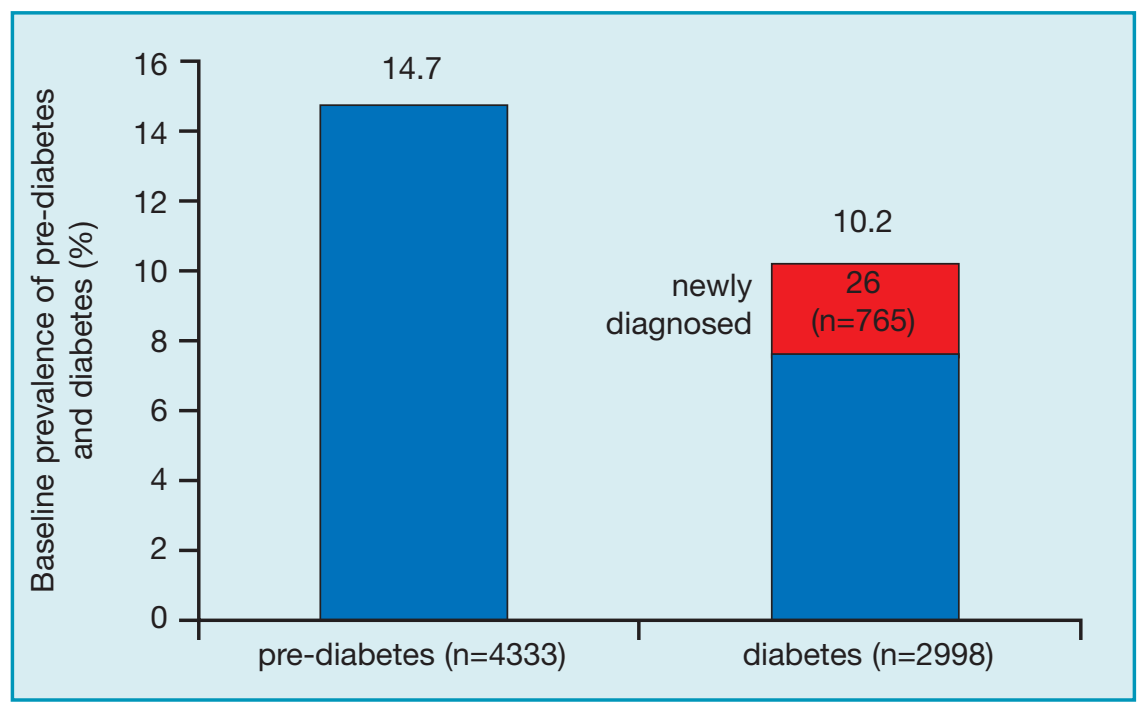

Figure 3. Baseline prevalence of pre-diabetes and diabetes among all WISEWOMAN participants screened at baseline (January 1998-June 2005)

heart disease risk factors among people with diabetes or pre-diabetes.

Results of our analysis are subject to several limitations. First, we do not have data on the changes that would have occurred among this population in the absence of participation in WISEWOMAN projects.

An assessment of trends in baseline risk factors (such as those presented in Figure 2 for mean blood glucose values) serves as an imperfect test of whether secular trends are driving the results. A decreasing trend in baseline risk factors across sixmonth cohorts of newly enrolled

\begin{tabular}{|l|l|l|l|}
\hline Variable & $\begin{array}{l}\text { Pre-diabetes } \\
\text { (n=688) }\end{array}$ & $\begin{array}{l}\text { Newly diagnosed } \\
\text { Diabetes } \\
\text { (n=83) }\end{array}$ & $\begin{array}{l}\text { Previously } \\
\text { diagnosed } \\
\text { Diabetes } \\
\text { (n=255) }\end{array}$ \\
\hline $\begin{array}{l}\text { Age (years) } \\
<55 \\
\geq 55\end{array}$ & 62.8 & 64.2 & \\
\hline $\begin{array}{l}\text { Race or ethnicity } \\
\text { White }\end{array}$ & 37.2 & 35.8 & 51.8 \\
$\begin{array}{l}\text { Black } \\
\text { Hispanic/Latina }\end{array}$ & 54.6 & 42.0 & 48.2 \\
$\begin{array}{l}\text { American Indian/ } \\
\text { Alaska Native }\end{array}$ & 12.2 & 12.3 & \\
Asian & 23.9 & 21.0 & 55.7 \\
Unknown & 1.3 & 18.5 & 9.1 \\
\hline $\begin{array}{l}\text { Education } \\
\text { < 12 years }\end{array}$ & 1.6 & 2.5 & 18.6 \\
$\begin{array}{l}\text { High school graduate } \\
\text { Some college }\end{array}$ & 18.2 & 3.7 & 0.4 \\
Missing education & 38.2 & 23.4 & 1.6 \\
\hline
\end{tabular}

Table 1. Demographic characteristics of WISEWOMAN participants with baseline and follow-up screenings (1998-2005) in 10 projects, by diabetes status (all figures are percentages) participants would suggest that other factors not related to WISEWOMAN may be associated with improvements among participants. However, over this six-year period, baseline blood glucose values among newly enrolled participants have increased significantly (Figure 2) and baseline BP and cholesterol values remained unchanged (trend was not statistically different from zero, results available upon request). Even among the general population of 40-64 year-old women, there is no evidence of decreasing blood glucose values (Figure 2).

Secondly, it is unclear whether the outcomes were a result of a single programme component or a combination. Evidence suggests that each WISEWOMAN component (i.e. screening, lifestyle intervention, referral services, and oneyear follow-up examination) has been effective in similar populations. ${ }^{4,14,15,20}$ Furthermore, in our previous work we found that some improvements in CHD risk factors among women with abnormal risk factors at baseline can be attributed to medication use, but most improvements are probably driven by a combination of other factors. These include the receipt of screening, risk factor counselling and lifestyle interventions. ${ }^{21}$

Thirdly, the WISEWOMAN programme has a low follow-up rate (23\%). WISEWOMAN participants are recruited from NBCCEDP; as a result, women who lose their eligibility for NBCCEDP because they obtain health insurance, increase their incomes, or reach 66 years of age are automatically ineligible for WISEWOMAN. Although we observed some statistically significant differences in demographic and baseline health characteristics between participants who returned and those who did not return for their one-year follow-up examination, the differences were fairly small (except for smoking 


\begin{tabular}{|c|c|c|c|c|c|}
\hline & $\mathbf{n}$ & $\begin{array}{l}\text { Baseline } \\
\text { mean (SE) }\end{array}$ & $\begin{array}{l}\text { Follow-up } \\
\text { mean (SE) }\end{array}$ & $\begin{array}{l}\text { Percentage } \\
\text { change }\end{array}$ & $\begin{array}{l}\text { p-value } \\
\text { for } \% \Delta\end{array}$ \\
\hline Pre-diabetes at baseline & & & & & \\
\hline SBP, mmHg & 639 & $\begin{array}{l}127.9 \\
(0.67)\end{array}$ & $\begin{array}{l}127.0 \\
(0.65)\end{array}$ & -0.7 & 0.11 \\
\hline DBP, mmHg & 637 & $\begin{array}{l}78.1 \\
(0.41)\end{array}$ & $\begin{array}{l}77.6 \\
(0.41)\end{array}$ & -0.7 & 0.19 \\
\hline $\mathrm{TC}, \mathrm{mmol} / \mathrm{l}$ & 688 & $\begin{array}{l}5.5 \\
(0.04)\end{array}$ & $\begin{array}{l}5.4 \\
(0.04)\end{array}$ & -2.1 & 0.00 \\
\hline Glucose, $\mathrm{mmol} / \mathrm{l}$ & 560 & $\begin{array}{l}6.0 \\
(0.01)\end{array}$ & $\begin{array}{l}5.8 \\
(0.04)\end{array}$ & -2.9 & 0.00 \\
\hline $\mathrm{BMI}, \mathrm{kg} / \mathrm{m}^{2}$ & 601 & $\begin{array}{l}32.5 \\
(0.30)\end{array}$ & $\begin{array}{l}32.3 \\
(0.31)\end{array}$ & -0.5 & 0.26 \\
\hline Smoking, \% & 676 & $\begin{array}{l}22.3 \\
(1.60)\end{array}$ & $\begin{array}{l}21.6 \\
(1.58)\end{array}$ & -3.3 & 0.41 \\
\hline 10-year CHD risk, \% & 602 & $\begin{array}{l}5.6 \\
(0.17)\end{array}$ & $\begin{array}{l}5.4 \\
(0.17)\end{array}$ & -4.3 & 0.02 \\
\hline Newly diagnosed diabetes & & & & & \\
\hline $\mathrm{SBP}, \mathrm{mmHg}$ & 81 & $\begin{array}{l}134.8 \\
(2.15)\end{array}$ & $\begin{array}{l}130.6 \\
(2.06)\end{array}$ & -3.1 & 0.03 \\
\hline $\mathrm{DBP}, \mathrm{mmHg}$ & 81 & $\begin{array}{l}81.2 \\
(1.26)\end{array}$ & $\begin{array}{l}78.3 \\
(1.24)\end{array}$ & -3.5 & 0.02 \\
\hline $\mathrm{TC}, \mathrm{mmol} / \mathrm{l}$ & 83 & $\begin{array}{l}5.7 \\
(0.13)\end{array}$ & $\begin{array}{l}5.4 \\
(0.12)\end{array}$ & -6.4 & 0.00 \\
\hline Glucose, $\mathrm{mmol} / \mathrm{l}$ & 59 & $\begin{array}{l}8.4 \\
(0.33)\end{array}$ & $\begin{array}{l}7.4 \\
(0.35)\end{array}$ & -11.5 & 0.02 \\
\hline BMl, kg/m² & 76 & $\begin{array}{l}34.4 \\
(1.02)\end{array}$ & $\begin{array}{l}34.3 \\
(0.87)\end{array}$ & -0.3 & 0.85 \\
\hline Smoking, \% & 82 & $\begin{array}{l}13.4 \\
(3.79)\end{array}$ & $\begin{array}{l}12.2 \\
(3.64)\end{array}$ & -9.1 & 0.71 \\
\hline 10-year CHD risk, \% & 70 & $\begin{array}{l}12.6 \\
(0.75)\end{array}$ & $\begin{array}{l}11.6 \\
(0.71)\end{array}$ & -8.4 & 0.07 \\
\hline Previously diagnosed diabetes & & & & & \\
\hline SBP, mmHg & 253 & $\begin{array}{l}131.7 \\
(1.14)\end{array}$ & $\begin{array}{l}129.2 \\
(1.07)\end{array}$ & -1.9 & 0.03 \\
\hline DBP, mmHg & 253 & $\begin{array}{l}79.0 \\
(0.63)\end{array}$ & $\begin{array}{l}76.3 \\
(0.57)\end{array}$ & -3.4 & 0.00 \\
\hline $\mathrm{TC}, \mathrm{mmol} / \mathrm{l}$ & 255 & $\begin{array}{l}5.5 \\
(0.07)\end{array}$ & $\begin{array}{l}5.3 \\
(0.07)\end{array}$ & -3.8 & 0.00 \\
\hline Glucose, $\mathrm{mmol} / \mathrm{l}$ & 128 & $\begin{array}{l}7.9 \\
(0.28)\end{array}$ & $\begin{array}{l}7.7 \\
(0.27)\end{array}$ & -2.2 & 0.50 \\
\hline $\mathrm{BMI}, \mathrm{kg} / \mathrm{m}^{2}$ & 236 & $\begin{array}{l}35.1 \\
(0.51)\end{array}$ & $\begin{array}{l}35.4 \\
(0.51)\end{array}$ & 0.6 & 0.20 \\
\hline Smoking, \% & 260 & $\begin{array}{l}16.1 \\
(2.29)\end{array}$ & $\begin{array}{l}12.3 \\
(2.04)\end{array}$ & -23.8 & 0.01 \\
\hline 10-year CHD risk, \% & 233 & $\begin{array}{l}12.3 \\
(0.46)\end{array}$ & $\begin{array}{l}11.2 \\
(0.40)\end{array}$ & -8.5 & 0.00 \\
\hline
\end{tabular}

Table 2: One-year changes in coronary heart disease (CHD) risk factors, by baseline diabetes status 
rates, which were $20 \%$ among those who returned and 25\% among those who did not return).

Finally, diabetes diagnoses were not confirmed by repeated blood glucose testing on a different day, as recommended by the American Diabetes Association and World Health Organization. ${ }^{5,7}$ Also, WISEWOMAN projects are permitted to use venous and capillary methods to measure blood glucose levels.

Our analysis shows that WISEWOMAN participants achieved clinically modest improvements in heart disease and stroke risk factors over a one-year period. If these small reductions could be sustained on a population-wide level, they could lead to large reductions in CHD morbidity and mortality. Moreover, a previous cost-effectiveness analysis of WISEWOMAN has shown that this programme compares favourably with other public health interventions aimed at improving CHD risk factors, even when considering the challenges and barriers of reaching this financially vulnerable population. ${ }^{22}$

Potential barriers to reaching the low-income, under-insured, and uninsured women served by WISEWOMAN include provider skepticism about women's ability to change their behaviours and the women's social isolation, unsafe neighbourhoods and lack of access to healthy foods: ${ }^{23-26}$ in some locations, for example, neighbourhood stores do not stock highquality, affordable fruits and vegetables or low-fat snacks. Because the women face many structural barriers, WISEWOMAN projects are encouraged to use the socioecological model ${ }^{27}$ to develop multifaceted interventions that address intrapersonal, organisational, community, and policy influences on health and health behaviours. For example, to strengthen family and peer support, which has been shown to improve health outcomes, ${ }^{28-32}$ some WISEWOMAN projects now invite relatives and friends to participate in the interventions. WISEWOMAN staff work collaboratively with women to change their behaviours.

Organisations are also developing creative strategies using WISEWOMAN funding. ${ }^{33}$ In North Carolina, for example, a county health department clinic partnered with a community free clinic to extend its operating hours so that WISEWOMAN participants could attend appointments more easily. At the community level, some projects have hired community healthcare workers from participants' neighbourhoods to conduct outreach, make telephone calls to encourage attendance at medical examinations and intervention sessions, arrange transportation, help find low-cost medications, and provide other support services. Some projects provide discount passes to encourage exercise in safe environments or discount coupons to community weight-loss programmes.

As WISEWOMAN projects explore ways to serve as agents of social change, they are building alliances among disadvantaged women and their families, healthcare providers, and neighbourhoods. The WISEWOMAN programme's ability to eliminate social-group disparities in diabetes incidence and mortality probably depends on the strength of these alliances. The goal of the WISEWOMAN programme in promoting more comprehensive interventions is to empower women to use all available services, to facilitate the adoption of a healthier lifestyle. The programme also hopes to garner the social support needed for behavioural change, raise providers' expectations, build trust between patients and providers, ensure that healthcare environments address the needs of culturally diverse populations effectively, remove community barriers to healthy lifestyles, and create advocates for better healthcare coverage.

If WISEWOMAN projects can successfully implement multilevel interventions and demonstrate their effectiveness, this approach is likely to be adopted on a much broader scale. As progress is made toward this goal, the WISEWOMAN programme will begin to realise its vision of a world where any woman can access preventive health services and gain the wisdom to improve her health.

\section{Acknowledgments}

We gratefully acknowledge the creativity and dedication of the WISEWOMAN project directors and coordinators. Without their efforts, this programme would not be possible.

\section{Conflict of interest statement:}

None

\section{Disclaimer:}

The findings and conclusions in this report are those of the authors and do not necessarily represent the views of CDC or RTI International.

\section{Further information:}

Appendices with a summary of the 10 projects, methods for estimating trends in mean fasting glucose values and characteristics of women at one-year follow-up are published online with the article at the European Diabetes Nursing home page on Wiley InterScience www.interscience.wiley.com

\section{References}

1. Mokdad AH, Ford ES, Bowman BA, $e t$ $a l$. Prevalence of obesity, diabetes, and obesity-related health risk factors, 2001. JAMA 2003; 289: 76-79.

2. The National Center for Chronic Disease Prevention and Health Promotion. Age specific prevalence of diagnosed diabetes, by race/ethnicity and sex, United States, 2004. 
www.cdc.gov/diabetes/statistics/prev/ national/fig2004.htm [Accessed 30 March 2007].

3. Harris MI, Flegal KM, Cowie CC, et al. Prevalence of diabetes, impaired fasting glucose, and impaired glucose tolerance in U.S. adults. The Third National Health and Nutrition Examination Survey, 1988-1994. Diabetes Care 1998; 21: 518-524.

4. Diabetes Prevention Program Research Group. Reduction in the evidence of type 2 diabetes with lifestyle intervention or metformin. $N$ Engl J Med 2002; 346: 393-403.

5. American Diabetes Association. Clinical practice recommendations 2006. Diabetes Care 2006; 29: S1-S85.

6. National Diabetes Information Clearinghouse. Diabetes, heart disease and stroke. http://diabetes. niddk.nih.gov/dm/pubs/stroke/ [Accessed 30 March 2007].

7. World Health Organization: Definition and diagnosis of diabetes mellitus and intermediate hyperglycaemia. Report of a WHO/IDF Consultation. Geneva: World Health Organization and International Diabetes Federation 2006.

8. Will JC, Farris RP, Sanders CG, et al. Health promotion interventions for disadvantaged women: overview of the WISEWOMAN projects. $J$ Womens Health (Larchmt) 2004; 13: 484-502.

9. Centers for Disease Control and Prevention (CDC). WISEWOMAN. www.cdc.gov/wisewoman/ [Accessed 30 March 2007].

10. American College of PhysiciansAmerican Society of Internal Medicine. No health insurance? It's enough to make you sick. Uninsured women at risk [White Paper]. Philadelphia: American College of Physicians-American Society of Internal Medicine 2001. www.acpon line.org/college/pressroom/unin sured_factsheet.htm [Accessed 30 March 2007].

11. Collins KS, Hall A, Neuhaus C. U.S. Minority Health: A Chartbook. New York: The Commonwealth Fund, 1999.

12. Institute of Medicine. Unequal Treatment: Confronting Racial and Ethnic Disparities in Health Care. Washington, DC: National Academies Press, 2003.

13. Centers for Disease Control and
Prevention (CDC). National Center for Health Statistics (NCHS). National Health and Nutrition Examination Survey Data. Hyattsville, MD: U.S. Department of Health and Human Services, Centers for Disease Control and Prevention, 1999-2004.

14. Chobanian AV, Bakris GL, Black HR, et al. The seventh report of the Joint National Committee on detection, evaluation and treatment of high blood pressure. Hypertension 2003; 42: 1206-1252.

15. National Cholesterol Education Program. Third report of the Expert Panel on Detection, Evaluation, and Treatment of High Blood Cholesterol in Adults (Adult Treatment Panel III). Bethesda, MD: National Heart, Lung, and Blood Institute, National Institutes of Health 2001. Publication 01-3670.

16. Anderson KM, Wilson PW, Odell PM, et al. An updated coronary risk profile. A statement for health professionals. Circulation 1991; 8: 356-362.

17. Finkelstein EA, Khavjou OA, Will JC, et al. Assessing the ability of cardiovascular disease risk calculators to evaluate effectiveness of trials and interventions. Expert Rev Pharmacoeconomics Outcomes Res 2006; 6: 417-424.

18. StataCorp. Stata Statistical Software: Release 9. College Station, TX: StataCorp LP 2005.

19. Murray D, Wolfinger R. Analysis issues in the evaluation of clinical trials: Progress toward solutions in SAS/STAT MIXED. J Community Psychol 1994; 22: 140-154.

20. Whitlock EP, Williams SB. The primary prevention of heart disease in women through health behavior change promotion in primary care. Womens Health Issues 2003; 13: 122-141.

21. Khavjou OA, Finkelstein EA, Will JC. Impact of medication use in a multicomponent intervention: results from the WISEWOMAN program. Am J Health Prom. In press.

22. Finkelstein E, Khavjou O, Will J. Costeffectiveness of WISEWOMAN, a program aimed at reducing heart disease risk among low-income women. $J$ Womens Health (Larchmt) 2006; 15: 379-389.

23. Williams DR, Collins C. Racial residential segregation: a fundamental cause of racial disparities in health. Public
Health Rep 2001; 116: 404-416.

24. Giles-Corti B, Donovan RJ. The relative influence of individual, social, and physical environment determinants of physical activity. Soc Sci Med 2002; 54: 1793-1812.

25. Morland K, Wing S, Diez-Roux A. The contextual effect of the local food environment on residents' diets: the atherosclerosis risk in communities study. Am J Public Health 2002; 92: 1761-1767.

26. Ainsworth BE, Wilcox S, Thompson WW, et al. Personal, social, and physical environmental correlates of physical activity in African-American women in South Carolina. Am J Prev Med 2003; 25: 23-29.

27. McLeroy K, Bibeau D, Steckler A, et al. An ecological perspective on health promotion programs. Health Educ $Q$ 1988; 15: 351-377.

28. Hogue CJ. Toward a systematic approach to understanding - and ultimately eliminating - African American women's health disparities. Womens Health Issues 2002; 12: 222-237.

29. Andajani-Sutjahjo S, Ball K, Warren N, et al. Perceived personal, social and environmental barriers to weight maintenance among young women: a community survey. Int J Behav Nutr Phys Act 2004; 1: 15.

30. Blanchard CM, McGannon KR, Spence JC, et al. Social ecological correlates of physical activity in normal weight, overweight, and obese individuals. Int $J$ Obes (Lond) 2005; 29: 720-726.

31. Gorin A, Phelan S, Tate D, et al. Involving support partners in obesity treatment. J Consult Clin Psychol 2005; 73: 341-343.

32. Verheijden MW, Bakx JC, van Weel C, et al. Role of social support in lifestylefocused weight management interventions. Eur J Clin Nutr 2005; 59: S179-S86.

33. Centers for Disease Control and Prevention. WISEWOMAN works: A Collection of Success Stories from Program Inception through 2002. Atlanta, GA: Centers for Disease Control and Prevention, National Center for Chronic Disease Prevention and Health Promotion 2003. www.cdc. gov/wisewoman/publications. htm\#success [Accessed 30 March 2007]. 
34. Rosamond WD, Ammerman AS, Holliday JL, et al. Cardiovascular disease risk factor intervention in lowincome women: the North Carolina WISEWOMAN project. Prev Med. 2000; 31: 370-379.

35. Calfas KJ, Sallis JF, Zabinski MF, et al. Preliminary evaluation of a multicomponent program for nutrition and physical activity change in primary care: PACE+ for adults. Prev Med 2002; 34: 153-161.

36. Dunn AL, Marcus BH, Kampert JB, et $a l$. Reduction in cardiovascular disease risk factors: 6-month results from Project Active. Prev Med 1997; 26: 883-892.

37. U.S. Department of Agriculture. Dietary Guidelines for Americans, 2000. http://www.health.gov/dietary guidelines/ [Accessed 30 March 2007]

38. Lindberg R. Active living: on the road with the 10,000 Steps program. J Am Diet Assoc 2000; 100: 878-879.

39. Iwane M, Arita M, Tomimoto S, et al. Walking 10,000 steps/day or more reduces blood pressure and sympathetic nerve activity in mild essential hypertension. Hypertens Res 2000; 23: 573-580.

Appendix A. Selected features the WISEWOMAN programmes.

\begin{tabular}{|c|c|c|c|c|c|}
\hline Feature & Connecticut & Illinois & Massachusetts & Missouri & Nebraska \\
\hline Year first funded & 2000 & 2001 & 1995 & 2003 & 2000 \\
\hline Lead agency & $\begin{array}{l}\text { Connecticut } \\
\text { Department of } \\
\text { Public Health }\end{array}$ & $\begin{array}{l}\text { Illinois Department } \\
\text { of Public Health }\end{array}$ & $\begin{array}{l}\text { Massachusetts } \\
\text { Department of } \\
\text { Public Health }\end{array}$ & $\begin{array}{l}\text { Missouri Department } \\
\text { of Health and Senior } \\
\text { Services }\end{array}$ & $\begin{array}{l}\text { Nebraska } \\
\text { Department of } \\
\text { Public Health }\end{array}$ \\
\hline $\begin{array}{l}\text { Participant } \\
\text { eligibility for } \\
\text { intervention }\end{array}$ & $\begin{array}{l}\text { Women with } \\
\text { abnormal blood } \\
\text { pressure or } \\
\text { cholesterol or who } \\
\text { use tobacco. }\end{array}$ & $\begin{array}{l}\text { All recruited } \\
\text { BCCEDP } \\
\text { participants aged } \\
\text { 40-64. }\end{array}$ & $\begin{array}{l}\text { Women with } \\
\text { abnormal blood } \\
\text { pressure or } \\
\text { cholesterol, and } \\
\text { other CVD risk } \\
\text { factors. }\end{array}$ & $\begin{array}{l}\text { All women, } \\
\text { regardless of } \\
\text { screening results }\end{array}$ & $\begin{array}{l}\text { All women, } \\
\text { regardless of } \\
\text { screening results }\end{array}$ \\
\hline $\begin{array}{l}\text { Features of } \\
\text { baseline } \\
\text { screenings and } \\
\text { risk factor } \\
\text { assessments }\end{array}$ & $\begin{array}{l}\text { Hypertension, } \\
\text { abnormal lipid } \\
\text { values, abnormal } \\
\text { glucose values, } \\
\text { abnormal pulse, } \\
\text { overweight, } \\
\text { physical inactivity, } \\
\text { poor diet, cigarette } \\
\text { smoking. }\end{array}$ & $\begin{array}{l}\text { Hypertension, } \\
\text { hypercholes- } \\
\text { terolemia, high } \\
\text { triglycerides, } \\
\text { abnormal glucose } \\
\text { values, abnormal } \\
\text { pulse, overweight, } \\
\text { abdominal obesity, } \\
\text { personal and family } \\
\text { medical history, } \\
\text { cigarette smoking, } \\
\text { poor diet, physical } \\
\text { activity. }\end{array}$ & $\begin{array}{l}\text { Hypertension, } \\
\text { abnormal lipid } \\
\text { values, abnormal } \\
\text { glucose values, } \\
\text { overweight, } \\
\text { physical inactivity, } \\
\text { poor diet, } \\
\text { cigarette smoking. }\end{array}$ & $\begin{array}{l}\text { Hypertension, } \\
\text { abnormal lipid } \\
\text { values, abnormal } \\
\text { glucose values, } \\
\text { overweight, personal } \\
\text { and family health } \\
\text { history, poor diet, } \\
\text { physical inactivity, } \\
\text { cigarette smoking. }\end{array}$ & $\begin{array}{l}\text { Hypertension, } \\
\text { abnormal lipid } \\
\text { values, abnormal } \\
\text { glucose values, } \\
\text { overweight, } \\
\text { personal history, } \\
\text { poor diet, } \\
\text { physical } \\
\text { inactivity, } \\
\text { cigarette } \\
\text { smoking. }\end{array}$ \\
\hline $\begin{array}{l}\text { Features of } \\
\text { Intervention } \\
\text { (nutrition and } \\
\text { physical } \\
\text { activity) }\end{array}$ & $\begin{array}{l}\text { Adaptation of } A \\
\text { New Leaf ...Choices } \\
\text { for Healthy Living }{ }^{34} \\
\text { for nutrition; PACE } \\
\text { program for } \\
\text { physical activity. }{ }^{35}\end{array}$ & $\begin{array}{l}\text { A 12-week nutrition } \\
\text { and format activity } \\
\text { group intervention } \\
\text { called Women with } \\
\text { Heart (based on } \\
\text { Project Active }{ }^{36} \text { ). } \\
\text { (A Spanish version, } \\
\text { Mujeres con } \\
\text { Corazón, is also } \\
\text { being used) } \\
\text { Sessions with health } \\
\text { educators focus on } \\
\text { portion sizes, food } \\
\text { labels, stress } \\
\text { management, and }\end{array}$ & $\begin{array}{l}\text { Individual } \\
\text { assessments, } \\
\text { education, and } \\
\text { lifestyle counseling } \\
\text { using the PACE } \\
\text { program. } \\
\text { Referred to } \\
\text { community- based } \\
\text { individual or group } \\
\text { interventions on } \\
\text { nutrition and } \\
\text { physical activity. }\end{array}$ & $\begin{array}{l}\text { Nutritionists, health } \\
\text { educators or } \\
\text { nursing staff use } \\
\text { the A New Leaf... } \\
\text { Choices for Healthy } \\
\text { Living }{ }^{34} \text { curriculum. }\end{array}$ & $\begin{array}{l}\text { Cooperative } \\
\text { Extension } \\
\text { nutritionists use } \\
\text { ABCs for Good } \\
\text { Health, }{ }^{37} \\
\text { participants } \\
\text { receive } \\
\text { individually } \\
\text { tailored nutrition } \\
\text { and physical } \\
\text { activity } \\
\text { interventions, } \\
\text { complete } \\
\text { monthly goal } \\
\text { assessment, and }\end{array}$ \\
\hline
\end{tabular}




\begin{tabular}{|l|l|l|l|l|l|}
\hline Feature & Connecticut & Illinois & Massachusetts & Missouri & Nebraska \\
\hline & $\begin{array}{l}\text { moderate physical } \\
\text { activity }\end{array}$ & $\begin{array}{l}10,000 \text { Steps } \\
\text { program. }^{38,39}\end{array}$ \\
\hline $\begin{array}{l}\text { Main Outcome } \\
\text { Variables }\end{array}$ & $\begin{array}{l}\text { Elevated blood } \\
\text { glucose, } \\
\text { hypertension and } \\
\text { hypercholes- } \\
\text { terolemia. }\end{array}$ & $\begin{array}{l}\text { Elevated blood } \\
\text { glucose, } \\
\text { hypertension and } \\
\text { hypercholes- } \\
\text { terolemia. }\end{array}$ & $\begin{array}{l}\text { Elevated blood } \\
\text { glucose, } \\
\text { hypertension and } \\
\text { hypercholes- } \\
\text { terolemia. }\end{array}$ & $\begin{array}{l}\text { Elevated blood } \\
\text { glucose, } \\
\text { hypertension and } \\
\text { hypercholes- } \\
\text { terolemia. }\end{array}$ & $\begin{array}{l}\text { Elevated blood } \\
\text { glucose, } \\
\text { hypertension, } \\
\text { obesity, and } \\
\text { hypercholes- } \\
\text { terolemia. }\end{array}$ \\
\hline
\end{tabular}

\begin{tabular}{|c|c|c|c|c|c|}
\hline Feature & North Carolina & $\begin{array}{l}\text { Southeast Alaska } \\
\text { Regional Health } \\
\text { Consortium }\end{array}$ & $\begin{array}{l}\text { Southcentral } \\
\text { Foundation }\end{array}$ & South Dakota & Vermont \\
\hline Year & 1995 & 2000 & 1999 & 2000 & 2000 \\
\hline Lead Agency & $\begin{array}{l}\text { North Carolina } \\
\text { Department of } \\
\text { Health and Human } \\
\text { Services }\end{array}$ & $\begin{array}{l}\text { SEARHC } \\
\text { Community } \\
\text { Health Services } \\
\text { Division }\end{array}$ & $\begin{array}{l}\text { Alaska Native } \\
\text { Medical Center }\end{array}$ & $\begin{array}{l}\text { South Dakota } \\
\text { Department of } \\
\text { Public Health }\end{array}$ & $\begin{array}{l}\text { Vermont } \\
\text { Department of } \\
\text { Public Health }\end{array}$ \\
\hline $\begin{array}{l}\text { Participant } \\
\text { eligibility for } \\
\text { intervention }\end{array}$ & $\begin{array}{l}\text { BCCEDP } \\
\text { participants aged } \\
40-64 \text { who are } \\
\text { screened with high } \\
\text { serum cholesterol } \\
\text { or other abnormal } \\
\text { lipids, elevated } \\
\text { systolic or diastolic } \\
\text { blood pressure or } \\
\text { abnormal glucose, } \\
\text { or a personal history } \\
\text { of these conditions. }\end{array}$ & $\begin{array}{l}\text { All women, } \\
\text { regardless of } \\
\text { screening results. }\end{array}$ & $\begin{array}{l}\text { All recruited } \\
\text { BCCEDP } \\
\text { participants aged } \\
40-64 \text { residing } \\
\text { within } 50 \text { miles of } \\
\text { the primary care } \\
\text { center. }\end{array}$ & $\begin{array}{l}\text { Preference given to } \\
\text { women with } \\
\text { abnormal screening } \\
\text { results. Women with } \\
\text { normal values can } \\
\text { self-refer to } \\
\text { intervention. }\end{array}$ & $\begin{array}{l}\text { All women, } \\
\text { regardless of } \\
\text { screening } \\
\text { results. }\end{array}$ \\
\hline $\begin{array}{l}\text { Features of } \\
\text { baseline } \\
\text { screenings and } \\
\text { assessments }\end{array}$ & $\begin{array}{l}\text { Hypertension, } \\
\text { hypercholes- } \\
\text { terolemia, other } \\
\text { abnormal lipids, } \\
\text { abnormal glucose } \\
\text { values, overweight, } \\
\text { personal and family } \\
\text { medical history, } \\
\text { cigarette smoking, } \\
\text { poor diet, physical } \\
\text { inactivity. Research } \\
\text { site includes the } \\
\text { above plus } \\
\text { red blood cell } \\
\text { membrane fatty } \\
\text { acid profiles and } \\
\text { blood carotenoids. }\end{array}$ & $\begin{array}{l}\text { Hypertension, } \\
\text { abnormal lipid } \\
\text { values, abnormal } \\
\text { glucose values, } \\
\text { overweight, } \\
\text { physical inactivity, } \\
\text { poor diet, cigarette } \\
\text { smoking. }\end{array}$ & $\begin{array}{l}\text { Hypertension, } \\
\text { ypercholes- } \\
\text { terolemia, high } \\
\text { triglycerides, other } \\
\text { abnormal lipids, } \\
\text { abnormal glucose } \\
\text { values, overweight, } \\
\text { abdominal obesity, } \\
\text { personal and family } \\
\text { medical history, } \\
\text { tobacco use, } \\
\text { poor diet, physical } \\
\text { inactivity. }\end{array}$ & $\begin{array}{l}\text { Hypertension, } \\
\text { abnormal lipid } \\
\text { values, abnormal } \\
\text { glucose values, } \\
\text { overweight, } \\
\text { personal history, } \\
\text { physical inactivity, } \\
\text { poor diet, cigarette } \\
\text { smoking. }\end{array}$ & $\begin{array}{l}\text { Hypertension, } \\
\text { abnormal lipid } \\
\text { values, abnormal } \\
\text { glucose values, } \\
\text { overweight, } \\
\text { physical } \\
\text { inactivity, poor } \\
\text { diet, cigarette } \\
\text { smoking. }\end{array}$ \\
\hline $\begin{array}{l}\text { Features of } \\
\text { intervention }\end{array}$ & $\begin{array}{l}\text { A New Leaf... } \\
\text { Choices for Healthy }\end{array}$ & $\begin{array}{l}\text { Patient educators } \\
\text { provide Traditions }\end{array}$ & $\begin{array}{l}\text { A 12-session group } \\
\text { covering traditional }\end{array}$ & $\begin{array}{l}\text { There are over } 80 \\
\text { lifestyle }\end{array}$ & $\begin{array}{l}\text { Nutritionists use } \\
\text { motivational }\end{array}$ \\
\hline
\end{tabular}




\begin{tabular}{|c|c|c|c|c|c|}
\hline Feature & North Carolina & $\begin{array}{l}\text { Southeast Alaska } \\
\text { Regional Health } \\
\text { Consortium }\end{array}$ & $\begin{array}{l}\text { Southcentral } \\
\text { Foundation }\end{array}$ & South Dakota & Vermont \\
\hline $\begin{array}{l}\text { (nutrition and } \\
\text { physical } \\
\text { activity) }\end{array}$ & $\begin{array}{l}\text { Living. }{ }^{34} \text { In the } \\
\text { physical community } \\
\text { center site, women } \\
\text { also receive follow- } \\
\text { up phone calls and } \\
\text { reminders from } \\
\text { community health } \\
\text { workers, and } \\
\text { referrals to } \\
\text { community } \\
\text { resources. }\end{array}$ & $\begin{array}{l}\text { of the Heart (cultural } \\
\text { adaptation of } \\
\text { A New Leaf... } \\
\text { Choices for Healthy } \\
\text { Living }^{34} \text { for Native } \\
\text { Alaskan } \\
\text { populations) at } \\
\text { time of screening. } \\
\text { Women also } \\
\text { referred to group- } \\
\text { based nutrition and } \\
\text { physical activity } \\
\text { interventions. }\end{array}$ & $\begin{array}{l}\text { wellness, nutrition, } \\
\text { physical activity } \\
\text { and tobacco } \\
\text { education topics, } \\
\text { team-taught by } \\
\text { nutritionists, } \\
\text { exercise } \\
\text { physiologists, and } \\
\text { health educators. } \\
\text { Includes Traditions } \\
\text { of the Heart, a } \\
\text { cultural adaptation } \\
\text { for Alaska Natives } \\
\text { of A New Leaf... } \\
\text { Choices for Healthy } \\
\text { Living. }{ }^{36} \text { Includes } \\
\text { structured diet and } \\
\text { physical activity } \\
\text { assessments, } \\
\text { individual counseling, } \\
\text { and tailored goal- } \\
\text { setting by health } \\
\text { educators. }\end{array}$ & $\begin{array}{l}\text { intervenetionists } \\
\text { (e.g. nutritionists, } \\
\text { nurses, extension } \\
\text { educators) across } \\
\text { the state offering } \\
\text { A New Leaf ... } \\
\text { Choices for Healthy } \\
\text { Living }{ }^{34} \text { for nutrition } \\
\text { assessment and } \\
\text { counseling; physical } \\
\text { activity intervention } \\
\text { modeled after } \\
\text { Project Active. }\end{array}$ & $\begin{array}{l}\text { interviewing to } \\
\text { provide } \\
\text { individualized } \\
\text { counseling that } \\
\text { encourage } \\
\text { women to adopt } \\
\text { healthy lifestyles. } \\
\text { They refer to } \\
\text { their lifestyle } \\
\text { intervention as } \\
\text { Turning Over a } \\
\text { New Leaf: } \\
\text { Healthy Choices } \\
\text { from Ladies } \\
\text { First. }\end{array}$ \\
\hline $\begin{array}{l}\text { Main outcome } \\
\text { variables }\end{array}$ & $\begin{array}{l}\text { Elevated blood } \\
\text { glucose, } \\
\text { hypertension and } \\
\text { hypercholes- } \\
\text { terolemia. }\end{array}$ & $\begin{array}{l}\text { Elevated blood } \\
\text { glucose, } \\
\text { hypertension and } \\
\text { hypercholes- } \\
\text { terolemia. }\end{array}$ & $\begin{array}{l}\text { Elevated blood } \\
\text { glucose, } \\
\text { hypertension and } \\
\text { hypercholes- } \\
\text { terolemia. }\end{array}$ & $\begin{array}{l}\text { Elevated blood } \\
\text { glucose, } \\
\text { hypertension and } \\
\text { hypercholes- } \\
\text { terolemia. }\end{array}$ & $\begin{array}{l}\text { Elevated blood } \\
\text { glucose, } \\
\text { hypertension and } \\
\text { hypercholes- } \\
\text { terolemia. }\end{array}$ \\
\hline
\end{tabular}

Appendix B. Mean fasting glucose values in the United States (1999-2004) and in the WISEWOMAN program (1998-2005)

\section{NHANES}

We used data from the 1999-2004 National Health and Nutrition Examination Survey (NHANES) Laboratory Assessment: Lab 10AM files from 1999-2000, 2001-2002, and 2003-2004 to estimate average glucose values among U.S. women aged 45-65. We estimated 2-year trends in average fasting glucose values by running a regression on glucose values with examination years (1999-2000, 2001-2002, or 2003-2004) as an independent variable. To account for the complex survey design of the NHANES data, we used svyset and svy: reg commands available in Stata; 17 we weighted the estimates with special fasting sample weights and estimated standard errors using appropriate strata and PSU variables. We divided the estimated 2-year trend $(0.0021 \mathrm{mmol}, \mathrm{p}=0.782)$ in average glucose values by four to obtain a 6 -month trend $(0.005$ $\mathrm{mmol})$. We then plotted average fasting glucose values among U.S. women aged 40-65 for years 1999-2004 using the estimated 6-month trend (Figure 2).

\section{WISEWOMAN}

We used 1998-2005 baseline WISEWOMAN data to estimate average fasting glucose values among newly enrolled program participants. We estimated 6-month trends $(0.017, p=0.00)$ in average fasting glucose levels by running a regression on glucose values with baseline screening examination periods as an independent variable. To account for demographic differences among WISEWOMAN cohorts enrolled at different time periods, we controlled for program location and participant age, race or ethnicity, and level of education. We then plotted average fasting glucose values among WISEWOMAN participants for years 1998-2005 using the estimated 6month trend (Figure 2). 
Appendix C. Characteristics of women who return and who do not return for a one-year follow-up visit

\begin{tabular}{|c|c|c|c|c|}
\hline \multicolumn{2}{|c|}{$\begin{array}{l}\text { The low re-screening rate among WISEWOMAN } \\
\text { participants is a concern because women who return } \\
\text { might not be representative of the whole WISEWOMAN } \\
\text { population, biasing the results. For example, women who } \\
\text { return for annual exams might be more likely to take care } \\
\text { of their health and be more motivated to change their } \\
\text { behavior (e.g., improve their diet or increase their physical } \\
\text { activity) than those women who do not return. If so, } \\
\text { women who return have greater improvements in risk } \\
\text { factors than women who do not and our results } \\
\text { overestimate the programmes effectiveness. } \\
\text { To assess the degree of potential bias introduced by low }\end{array}$} & \multicolumn{3}{|c|}{$\begin{array}{l}\text { re-screening rates, we assessed differences in } \\
\text { demographic and baseline health characteristics between } \\
\text { women who do and do not return for an annual follow-up } \\
\text { visit (Table C- } 1 \text { ). Although some of the differences we } \\
\text { found in demographic characteristics were statistically } \\
\text { significant, they were fairly small. However, those who } \\
\text { return are less likely than those who do not return to } \\
\text { smoke at baseline ( } 20 \% \text { versus } 25 \% \text { ) but are more likely } \\
\text { to have baseline hypertension ( } 36 \% \text { versus } 34 \%) \text {. These } \\
\text { results indicate that it is unlikely that our results were } \\
\text { affected by selection bias. }\end{array}$} \\
\hline Characteristic & \multicolumn{2}{|c|}{$\begin{array}{l}\text { With annual follow-up } \\
\text { exam }(n=1026)\end{array}$} & $\begin{array}{l}\text { Without annual } \\
\text { follow-up exam }(n=3307)\end{array}$ & $\begin{array}{l}\text { p-value of } \\
\text { difference }\end{array}$ \\
\hline Age, years & \multicolumn{2}{|l|}{50.5} & 50.1 & 0.00 \\
\hline Race or ethnicity (\%) & & & & \\
\hline White non-Hispanic & \multicolumn{2}{|l|}{61} & 61 & 0.79 \\
\hline Black non-Hispanic & \multicolumn{2}{|l|}{8} & 9 & 0.06 \\
\hline Hispanic & \multicolumn{2}{|l|}{14} & 15 & 0.02 \\
\hline Asian/Pacific Islander & \multicolumn{2}{|l|}{2} & 3 & 0.00 \\
\hline American Indian or Alaska Native & \multicolumn{2}{|l|}{14} & 10 & 0.00 \\
\hline \multicolumn{5}{|l|}{ Education (\%) } \\
\hline Less than 9th grade & \multicolumn{2}{|l|}{10} & 12 & 0.00 \\
\hline Some high school & \multicolumn{2}{|l|}{10} & 11 & 0.08 \\
\hline High school graduate & \multicolumn{2}{|l|}{44} & 41 & 0.00 \\
\hline $\begin{array}{l}\text { Some college or higher education } \\
\text { Health status }(\%)\end{array}$ & \multicolumn{2}{|l|}{36} & 36 & 0.96 \\
\hline Hypertension (BP $\geq 140 / 90$ or meds) & \multicolumn{2}{|l|}{36} & 34 & 0.03 \\
\hline Abnormal total cholesterol level & \multirow{2}{*}{\multicolumn{2}{|c|}{28}} & \multirow{3}{*}{26} & \multirow{3}{*}{0.06} \\
\hline (TC $\geq 240$ or meds) & & & & \\
\hline $\begin{array}{l}\text { Diabetes (FG } \geq 126, N F G \geq 200, \\
\text { self-reported diagnosis, or taking }\end{array}$ & & & & \\
\hline medications for diabetes) (\%) & \multicolumn{2}{|l|}{9} & 10 & 0.07 \\
\hline Obese (BMI $\geq 30)(\%)$ & \multicolumn{2}{|l|}{33} & 33 & 0.89 \\
\hline Smoker (\%) & \multicolumn{2}{|l|}{20} & 25 & 0.00 \\
\hline
\end{tabular}

Table C-1. Baseline demographic and risk factor characteristics of WISEWOMAN participants with and without follow-up exams 